\title{
PROPOSING A STRATEGIC CAPABILITY INDEX FOR MICRO AND SMALL ENTERPRISES
}

\section{ABSTRACT}

Organizations depend on their ability to formulate, implement and evaluate strategies effectively in order to make better use of their resources and capabilities to achieve and maintain competitive advantage. Regarding micro and small enterprises (MSE), which mortality levels are significant, those capacities are fundamental conditions for their survival and growth. Considering the lack of a more robust method of measuring strategic capability for this type of companies, this study proposes a Strategic Capability Index (SCI) for MSE. The research population was composed of companies located in the state of Ceará, Brazil, from a sample of 196 companies. By means of the application of a second order Confirmatory Factorial Analysis, it was possible to propose the factored index in five dimensions: Strategic Approach; Strategic Tools; Strategic Relations; Analysis of Environments; Strategic Processes. The SCI for MSE in the organizations analyzed in Ceará was low, implying the relative lack of competitiveness of these organizations.

Keywords: Strategic Capability; MSE; Strategic Capability Index; SCI; Confirmatory Factorial Analys is.

\section{PROPOSIÇÃO DE UM ÍNDICE DE CAPACIDADE ESTRATÉGICA PARA MICRO E PEQUENAS} EMPRESAS

\section{RESUMO}

As organizações dependem de suas capacidades de formular, implementar e avaliar estratégias de maneira eficaz, com o fim de melhor utilizar seus recursos e capacidades em busca da vantagem competitiva. Para as micros e pequenas empresas (MPE), cujo o nível de mortalidade é significativo, essa capacidade é a condição fundamental para sua sobrevivência e crescimento. Considerando a falta de métodos mais robustos de aferição da capacidade estratégica de referidas empresas, este estudo objetiva propor a elaboração de um índice de capacidade estratégica de MPE. A população da pesquisa foi formada por empresas localizadas no estado do Ceará, Brazil, com uma amostra de 196 empresas. Por meio da aplicação de uma Análise Fatorial Confirmatória de segunda ordem, foi possível a proposição do índice fatorado em cinco dimensões: enfoque estratégico; ferramentas estratégicas; relações estratégicas; análise de ambientes; e processo estratégico. O índice de capacidade estratégica de MPE das organizações cearenses analisadas mostrou-se baixo, implicando relativa falta de competitividade dessas organizações no mercado.

Palavras-chave: Capacidade Estratégica; MPE; Índice de Capacidade Estratégica; Análise Fatorial Confirmatória. 
PROPOSICIÓN DE UN ÍNDICE DE CAPACIDAD ESTRATÉGICA PARA MICRO Y PEQUEÑAS

EMPRESAS

\section{RESUMEN}

Las organizaciones dependen de sus capacidades de formular, implementar y evaluar estrategias de manera eficaz, con el fin de mejor utilizar sus recursos y capacidades en busca de la ventaja competitiva. Para las micro y pequeñas empresas (MPE), cuyo nivel de mortalidad es significativo, esta capacidad es la condición fundamental para su supervivencia y crecimiento. Considerando la falta de métodos más robustos de evaluación de la capacidad estratégica de dichas empresas, este estudio tiene como objetivo proponer la elaboración de un índice de capacidad estratégica de MPE. La población de la encuesta fue de MPE ubicadas en el estado de Ceará, Brazil, con una muestra de 196 empresas. Por medio de la aplicación de un Análisis Factorial Confirmatorio de segundo orden, fue posible la proposición del índice factorizado en cinco dimensiones: enfoque estratégico; herramientas estratégicas; relaciones estratégicas; análisis de ambientes; y proceso estratégico. El índice de capacidad estratégica de MPE de las organizaciones cearenses analizadas se mostró bajo, implicando relativa falta de competitividad de esas organizaciones en el mercado.

Palabras clave: Capacidad Estratégica; MPE; Índice de Capacidad Estratégica; Análisis Factorial Confirmatorio.

\footnotetext{
${ }^{1}$ Doutoranda em Administração de Empresas pela Universidade de Fortaleza - UNIFOR. Professora de niversidade de Fortaleza - UNIFOR e da Faculdades Nordeste - FANOR. Brasil. E-mail: sarahmesquitalima@gmail.com

${ }^{2}$ Mestre em Administração de Empresas pela Universidade de Fortaleza - UNIFOR. Professora do Centro Universitário Doutor Leão Sampaio - UNILEÃO. Brasil. E-mail: joycea 20@ hotmail.com

${ }^{3}$ Doutor em Administração de Empresas pela Escola de Administração de Empresas de São Paulo de Fundação Getulio Vargas - EAESP/FGV. Professor da Universidade de Fortaleza - UNIFOR. Brasil. E-mail: sergioforte@unifor.br

4 Mestre em Administração de Empresas pela Universidade de Fortaleza - UNIFOR. Brasil. E-mail: henriquelyramaia@gmail.com
} 


\section{INTRODUCTION}

Considering the unstable environment in which organizations are inserted, strategic capability becomes essential for those that seek to maintain and or grow in the market, such micro and small enterprises (MSE).

However, MSE face many difficulties when the issue is strategic capability, which is related to the ability of coordinating activities using their resources (Desarbo, Di Benedetto, Song \& Sinha, 2005).

The MSE's are of paramount importance in promoting the country's economic growth, being the main wealth generators in Brazil's commerce $53.4 \%$ of this sector's GDP); in industry, the GDP of MSE $(22.5 \%)$ is already close to the GDP of medium-sized enterprises $(24.5 \%)$. In the services sector, more than a third of the national production $(36.3 \%)$ is originated from small businesses (Brazilian Service of Support to Micro and Small Businesses [Sebrae], 2014).

It is important to mention that in the state of Ceará, as well as in the rest of Brazil, MSE's have a fundamental role in income generation, since these organizations are responsible for $49 \%$ of the jobs created (Sebrae and the Department of Statistics and Socioeconomic Studies, 2013). Also, it should be pointed out that, among the Brazilian Northeastern States, except for Ceará and Bahia, the aggregated value of participation from all those states together has fallen (Sebrae, 2015).

Thereby, understanding MSE management is the first step to acknowledge their level of strategic capability, as business management is directly related to the evaluative dimensions of strategic capability and the generation of competitive advantage (Ribeiro, 2008).

In that way, the development of the state of Ceará is significantly supported by the success of its MSE, the organizations responsible for maintaining the level of employment and for effectively combating unjust income distribution. Therefore, the importance of measuring strategic capability in MSE becomes evident.

Thus, in order to understand the relation between business processes and organizational effectiveness, the following research question emerges: What scores can be established in the constructs of the strategic capability index in Brazilian MSE?

In order to find evidence to support this proposition, and having in mind the growing importance of the subject for both the corporative environment as for the theory, this paper has the general goal of elaborating a strategic capability index for MSE. As specific goals, it is sought: (1) To theoretically align the concept of MSE and strategic capacities in business' strategy; (2) Identify the construct scores for strategic capabilities; (3) Define the strategic capacities assessment index in Brazilian MSE.
In order to reach the mentioned objectives, this study adopts a quantitative methodology with a survey strategy, using the Factorial Confirmatory Analysis (FCA), on the purpose of confirming the number of constructs and their compliance with the theoretical basis for the formation of the strategic capability index for MSE (Malhotra, 2006).

The elaboration of indexes has been a widely used resource to measure and monitor phenomena in many economic and social dimensions. In a competitive market, these indexes are applied in organizations as an essential tool, capable of generating a competitiveness differential. Therefore, measuring the profit on a company's trade, based on its strategic capabilities, can be a major challenge, and how to do so can define the success or failure of an organization (Almeida, 2001; Programa das Nações Unidas para o Desenvolvimento - PNUD, 2007; Pinto, 2001).

It is relevant and timely the accomplishment of this study, since it seeks to answer the mentioned questioning, which is based on results of other researches (Boohene, 2009; Dias, Cassol, Tonial, \& Rossetto, 2013; Grandee, 2014; Johannesson \& Palona, 2010), as well as to methodologically improve them.

\section{THEORETICAL FRAMEWORK}

The theoretical framework of this project has three developments, in which Strategic Capability will be presented, secondly MSE, and finally, some previous researches that have approached the issues discussed in this paper.

\subsection{Strategic Capability}

The interdisciplinary concept of strategy has several approaches, models and interpretations that hinder its use and evaluation. The strategic capacity of a company refers to its ability to successfully implement competitive strategies that shall allow it to survive and increase its value over time (Hartman, 2013).

As so, it is important to highlight the difference between the strategic capacity and the strategies of a company, once that while the strategies can be understood as ways of a company to planits future, being integrated in the decision making process, based on formal and articulated procedures for results, the strategic capacity of a company refers to an ensemble of all its capabilities, resources and organizational tools that potentiate the company's strategies for obtaining competitive advantage (Bannister \& Higgins, 1991, Harrison \& Miller 1999; Hartman, 2013, Johannesson \& Palona, 2010; Mintzberg, Ahlstrand, \& Lampel, 2000).

The strategic capacity of an organization refers to the accumulated skills and knowledge to coordinate 
its activities using its assets, always with the purpose of sustaining its competitive advantage, that is, using the best skills and strategies that the company has to prevail over its competitors (Desarbo et al., 2005).

When there is a balance between strategy and strategic capacity, the organization's performance is optimized in a peculiar business environment (Ansoff, 1984). Thereby, a company that aims to survive and thrive in a competitive environment needs to enhance its strategic capability. The type of strategic capacity that the firm needs at a given moment is determined by the forces of legitimacy, threats and opportunities in future business environments (Ansoff, 1984).

One way of identifying strategic capacity is based on the Firm's Resource-Based View (VBR)
(Barney, 1991; Collis \& Montgomery, 1995; Dierickx $\&$ Cool, 1989; Wernerfelt, 1984). From the perspective of this theory, a company's capabilities form a subset of resources (Penrose, 1959), which are the tangible and intangible assets required for the company to enter its strategy for a competitive advantage (Barney, 1990; Porter, 1985; Wernerfelt, 1984). These organizational capacities, when abundant, make the company survive more easily, forming the basis for its development in relation to its competitors, thus increasing its strategic capacity.

For Desarbo et al. (2005), the strategic capacity of a company can be divided into five distinct dimensions, presented in Figure 1.

Figure 1 - Types of Strategic capacities

\begin{tabular}{|c|c|}
\hline STRATEGIC CAPACITIES & ANALISYS CATEGORIES \\
\hline Business Administration & $\begin{array}{l}\text { - Human resources management; } \\
\text { - Financial management; } \\
\text { - Marketing strategy administration; } \\
\text { - Logistics Systems; } \\
\text { - Quality control, sustaintability and inovation programs. }\end{array}$ \\
\hline Marketing & $\begin{array}{l}\text { - Market place and segmentation; } \\
\text { - Competitive Advantage: prices and advertising; } \\
\text { - Marketing programs. }\end{array}$ \\
\hline Market aiming & $\begin{array}{l}\text { - Contact channels, public and sources; } \\
\text { - Client monitoring technology. }\end{array}$ \\
\hline Information technology & $\begin{array}{l}\text { - Integrated systems; } \\
\text { - Internal and external data. }\end{array}$ \\
\hline Technological & $\begin{array}{l}\text { - Efficient production process; } \\
\text { - Costs reduction; } \\
\text { - Products and processes development. }\end{array}$ \\
\hline
\end{tabular}

Source: Adapted from Desarbo, W. S., Di Benedetto, C. A., Song, M. \& Sinha, I. (2005). Revisiting the Miles and Snow Strategic Framework: Uncovering Interrelationships between Strategic Types, Capabilities, Environmental Uncertainty, and firm Performance. Strategic Management Journal, 26 (1), 47-74.

The organization that makes use of these dimensions of strategic capacity may respond more quickly to the environment and its changes, thus making it possible to benefit from the opportunities that the environment offers and, consequently, create a competitive advantage (Desarbo et al., 2005).

Organizational competitiveness, once focused on physical and tangible resources, is now more focused on knowledge and intangible resources (Kaplan \& Norton, 2004; Low \& Kalafut, 2003; Wong \& Aspinwall, 2005). Considering that in Brazil, as in many other countries, most companies are small and medium-sized, they play a fundamental role in driving the economies of their countries (Edvardsson \& Durst, 2013).

Faced by a worldwide competitive scenario, Canzano and Grimaldi (2012) argue that organizations need to manage effectively their strategic capacities to achieve success. However, Nunes, Annansing, Eaglestone and Wakefield (2006) emphasize that strategic capacity in the form of knowledge management is neglected by MSE, what leads to a high mortality rate for these companies.

In this sense, several studies (Cezarino \& Campomar, 2006; Dornelas, 2008; Dumbu \& Chadamoyo, 2012; Herrera, 2007; Small Business Administration - SBA, 2013; Sebrae, 2010; Terence, 2002; Tlhomola, 2010; Trindade, Macedo, Gauthier, Botelho \& Lanblak, 2016) demonstrate that MSE suffer from structural problems in their management, influencing their strategic capacities.

Considering the facts exposed, and according to previous studies (Aaker, 2001; Moen, 1999; Perin \& Sampaio, 2004), larger companies have more resources and then they are more able to become competitive, 
what makes it worthy to promote a deeper understanding about the MSE.

\subsection{MSE}

MSE play a key role in developing economies (Davood \& Mousakhani, 2012; Porter, 1986). It should be noted that the importance of this type of enterprise goes beyond macroeconomic issues, but much further, as, for instance, leading to poverty reduction and job creation (Davood \& Mousakhani, 2012).

Although some studies (Global Entrepreneurship Monitor - GEM, 2014) point to significant improvements on of MSE performance over the years, there are still critical deficiencies of resources and capabilities in these organizations, factors that can directly influence the competitiveness of these companies in the market.

In this sense, Cezarino and Campomar (2006) point out three aspects found in the Brazilian MSE administration that construct a clear image of how these organizations are characterized in Brazil. They are: (1) Informal management: this aspect highlights the high degree of centralization in the figure of the entrepreneur, which can turn the company dependent and cast; (2) Low managerial quality: it is pointed out as an unfolding of informal management, emphasizing that the lack of quality is reflected in the absence of information about processes, controls, lack of knowledge of the market and inability to build a competitive strategy, and difficulty in decision making; and (3) Scarcity of resources: Brazilian MSE are scarce in resources and have difficulties in raising public and private funding.

That is corroborated and reinforced by other studies, which point out that most MSE are managed by their owners and family members, who mostly have not gotten technical qualification, acting in an empirical way, without administrative concepts of their own business or a defined plan of action (Lima \& Vasconcelos, 2016; Maia, 2017; Vieira, 2007); the owner and the few employees receive several strategic assignments, which means that the absence or dismissing of one of these people can cause a great loss or even the end of the company (Durst \& Wilhelm, 2013; Gerber, 1995). It is worth pointing out that to overcome adversity, MSE need to be able to change the organization and create favorable business environments to obtain competitive advantage (Mathaisel \& Comm, 2011).

MSE, due to their lean staff and structure, are also known for their great mobility, being able to absorb the changes in the market (Alves, 2003). Because they usually do not have many resources to spend, MSE should do more with less, that is, to be efficient (Desouza \& Awazu, 2006). In this context, the systematic use of people's knowledge can be an alternative to obtain competitive advantage, since knowledge multiplies when it is shared, unlike what happens with land, capital and labor (Nonaka \& Takeuchi, 2008).

There so, it is also necessary to keep a strategic management focused at creating conditions that will allow to identifying and bring up relevant resources and competencies, as well as implementing a strategy aligned to the environment, so that their competitors will not beable to imitate it easily (Collis \& Montgomery, 1995; Johannesson \& Palona, 2010; Lerner \& Almor, 2002).

The capabilities and resources required by the company at a given moment are defined by its strengths, weaknesses, threats and opportunities in the present and future business environment. Thereby, the dynamic capabilities theory argues that an organization's capabilities and resources are continuously adapted, integrated and reconfigured so that the organization can respond to market changes quickly, deploying strategies to use its internal resources to suit the external environment and gain competitive advantage (Helfat \& Peteraf, 2003).

In accordance to that, it is relevant to observe previous national and international studies that were aimedon analyzing strategic capacity, some of them focused on MSE.

\subsection{Previous Studies}

Many studies tried to analyze strategic capabilities of businesses and entrepreneurs and their impact on competitive advantage and firm performance. Some studies focused in SME (small and medium-sized companies) environment, where the entrepreneur has a key role on its success or failure (Gerber, 1995).

Other studies focused on the strategic capabilities by itself and did not discriminate or focused in any type, size or form of organization. For the SME segment, Carraresi, Mamaqi, Albisu and Banterle (2015) analyzed 67 small and medium-sized businesses in Italy their strategic capabilities and influence on competitive advantage. The study found that marketing, network and innovation capabilities positively affected their performance. Another recent study made in Brazil with entrepreneur's planning capability, suggested that it could exist two different types of entrepreneurs. The first one is more impulsive and opportunist, while the other one is more prone to planning (Nassif, Hashimoto \& Amaral, 2014). The authors suggested that it might be possible that in earlier stages the entrepreneur uses resources available and try to match it with opportunities available in the market. As the business grow, entrepreneurs will slowly be more prone to planning. Another study made by Gutiérrez, Fuentes and Ariza (2014) analyzed the relationship between strategic capabilities and performance in Mexico women-owned businesses. They used a sample of 90 businesses and they concluded that market orientation and learning orientation have a positive effect on firm performance. 
A larger sample study with 292 manufacturing firms in Canada and France analyzed how SME companies arranged their organizational capability configurations (Raymond \& St-Pierre, 2011). They classified strategic capabilities into product development, market development, networking, technological and HR capabilities and found three clusters of different strategic configurations.

Finnaly, it is important to highlight the works of Lerner and Almor (2002) - they analyzed 220 small Israeli companies - and Boohene (2009) - 600 small companies, focusing their business performance, and presented results that corroborate each other, revealing that the performance of the companies studied is highly correlated with certain aspects of the business owner's ability, since the managers of the surveyed companies had little management capacity and the strategies, skills and resources of their ventures were considered weak, along with their levels of strategic capacity, directly influencing the business' performance.

Some studies used somehow a larger type of businesses in their sample. Pearson, O'Connell, Pitfiel and Ryley (2015), analyzed strategic capabilities of 22 Top Asian network airlines to compete with low-cost carriers. They found that a positive correlation with strategic capabilities and firm performance, which means that performance can be increased if a company improves its own strategic capabilities.

Johannesson and Palona (2010) analyzed how the business environment influences the strategic capability of an organization. For the authors, the concept of strategic capability and its blending to strategic planning processes in companies have not been sufficiently explored and disseminated. The referred authors consider that strategic capability is characterized as the ability to change the organization and create favorable business environments to obtain competitive advantage. From this understanding, strategic capacity can be assessed through strategic resources and competencies, and comprehend the stakeholder aspirations, organizational competence and individual competence.

Regarding this theme, Grandee (2014) considers that if there is a collaborative process in the elaboration and implementation of plans and strategies, effective management for small business growth will be positively influenced.

Pisano's (2016) research argues that the research program on capabilities needs to be reorganized around the fundamental business strategy problem: how to identify and select capacities that lead to competitive advantage. To do so, the study developed a structure that tries to connect research strategies in the capacity of companies with their strategies in the product markets. Finally, the author suggests a research agenda on capabilities.

Nationally, Dias et al. (2013) aimed at understanding the periods of strategic adaptation of Celulose Irani S.A between 1994 and 2012, correlating them with strategic capabilities, using the strategic dimensions proposed by Desarbo et al. (2005).

On their turn, Vargas and Gonçalo (2013) analyzed the strategic capabilities required for innovation in information technology companies. The results evidenced that the capacities to create knowledge, technological capacity and market orientation are preponderant. Such capacities have been identified as strategic structuring capacities, which aim to promote greater performance with innovation by information technology organizations.

Silva and Ayres (2008) propose a model of identification of the sources of training of the strategic capabilities of the operation, in order to evaluate the relationship between the partners and organizational learning. The variables of the proposed model are oriented to categorize the sources of knowledge used by organizations.

Finally, the study by Oliveira and Sade (2016) investigated how the practices of competitive intelligence, which can be understood in the context under analysis as a strategic capacity, have been conducted by the mining companies of tin artifacts. From a sample of $90 \%$ of the tin companies operating in the respective region, the results revealed that strategic capability has been used in a practically informal manner, especially by the smallest companies.

In sum, most of the studies on strategic capabilities were mainly empirical and tried to analyze the relationship between strategic capabilities and firm performance. Many of them classified capabilities using RBV framework and mixed with industry and market analysis to stablish a connection between internal resources and external opportunities. After a review of previous studies, we proposed a strategic evaluation index for MSE, using quantitative and descriptive methodology to fulfill this objective.

Although there are similarities among those studies, it is valid to remark that the concept of strategic capability is still imprecise. Most of the studies explore the issue of strategic capabilities in specific sectors with little empirical evidence; hence, this research intended to fill the gap encountered in the present literature.

\section{MATERIALS AND METHODS}

This study, regarding its objectives, is conceived as an explanatory one (Jung, 2004). Regarding its approach, this research is essentially quantitative, but prior to this phase a qualitative analysis was performed. This phase of qualitative nature consisted of the consultation of five experts from the strategy area, with the aim of evaluating 58 variables for the elaboration of the pre-test. It should be noted that these 58 variables were listed in consultation with the strategy literature. 
After the validation phase by experts and the realization of the pre-tests, 29 variables were listed as the most applicable to the context under study. It is worth reminding, in order to make the constructs more strongly represented, the variables were adjusted in a total of six dimensions, according to Figure 2.

Figure 2 - Dimensions and variables that outline strategic capacity

\begin{tabular}{|c|c|c|}
\hline DIMENS IONS & OBSERVABLE VARIATIONS & THEORETICAL BASIS \\
\hline \multirow{4}{*}{$\begin{array}{l}\text { Strategic } \\
\text { approach }\end{array}$} & Organizational future vision & $\begin{array}{l}\text { Barney and Hesterly (2011), Cezarino and } \\
\text { Campomar (2006) and Collins and Porras } \\
\text { (2004). }\end{array}$ \\
\hline & Strategic thinking and culture & $\begin{array}{l}\text { Barney and Hesterly (2011), Cezarino and } \\
\text { Campomar (2006), Hoskisson, Hitt, Ireland, } \\
\text { and Harrison (2009) and Mintzberg et al. } \\
(2000) \text {. }\end{array}$ \\
\hline & Entrepreneurial capability & $\begin{array}{l}\text { Cezarino and Campomar (2006), Gerber, 1995, } \\
\text { Gimenez (2000), Mintzberg et al. (2000), } \\
\text { Nassif, Hashimoto and Amaral, } 2014 \text { and } \\
\text { Sebrae (2010). }\end{array}$ \\
\hline & $\begin{array}{l}\text { Focus on aligning aims and goals to } \\
\text { the company's mission }\end{array}$ & $\begin{array}{l}\text { Barney and Hesterly (2011), Cezarino and } \\
\text { Campomar (2006), Hoskisson et al. (2009) and } \\
\text { Mintzberg et al. (2000). }\end{array}$ \\
\hline \multirow{4}{*}{$\begin{array}{l}\text { Strategic } \\
\text { process }\end{array}$} & Formally defined aims and goals & $\begin{array}{l}\text { Barney and Hesterly (2011), Cezarino and } \\
\text { Campomar (2006), Hoskisson et al. (2009) and } \\
\text { Mintzberg et al. (2000). }\end{array}$ \\
\hline & Formalized business plan & $\begin{array}{l}\text { Barney and Hesterly (2011), Cezarino and } \\
\text { Campomar (2006), Hoskisson et al. (2009), } \\
\text { Mintzberg et al. (2000) and Terence (2002). }\end{array}$ \\
\hline & Strategic planning system & $\begin{array}{l}\text { Barney and Hesterly (2011), Cezarino and } \\
\text { Campomar (2006), Grandee (2014), Hoskisson } \\
\text { et al. (2009), Mintzberg et al. (2000), Pearson } \\
\text { et al. (2015) and Terence (2002). }\end{array}$ \\
\hline & $\begin{array}{l}\text { Formalized mission, vision, values and } \\
\text { policies }\end{array}$ & $\begin{array}{l}\text { Barney and Hesterly (2011), Cezarino and } \\
\text { Campomar (2006), Hoskisson et al. (2009) and } \\
\text { Mintzberg et al. (2000). }\end{array}$ \\
\hline \multirow{5}{*}{$\begin{array}{l}\text { Analysis of } \\
\text { environments }\end{array}$} & $\begin{array}{c}\text { Industry analysis } \\
\text { (sources, rivals, buyers, substitute } \\
\text { products) }\end{array}$ & $\begin{array}{l}\text { McGahan (2004), Mintzberg et al. (2000), } \\
\text { Porter (1986) and Sebrae (2010). }\end{array}$ \\
\hline & Competition analysis & $\begin{array}{l}\text { Desarbo et al. (2005), Mintzberg et al. (2000), } \\
\text { Porter (1986) and Sebrae (2010). }\end{array}$ \\
\hline & Market analysis & $\begin{array}{l}\text { Desarbo et al. (2005), Johannesson and Palona } \\
\text { (2010), Mintzberg et al. (2000), Morais and } \\
\text { Soares (2016), Paim, Lara and Christino (2011), } \\
\text { Porter (1986) and Sebrae (2010). }\end{array}$ \\
\hline & Potential clients' analys is & $\begin{array}{l}\text { Desarbo et al. (2005), Kotler and Kelvin } \\
(2006) \text {, Porter (1986) and Sebrae (2010). }\end{array}$ \\
\hline & Company's market view evaluation & $\begin{array}{l}\text { Desarbo et al. (2005), Kotler and Kelvin } \\
\text { (2006), Mintzberg et al. }(2000) \text {, Pisano, 206, } \\
\text { Raymond and St-Pierre }(2011) \text { and Sebrae } \\
(2010) \text {. }\end{array}$ \\
\hline \multirow{3}{*}{ Strategic tools } & $\begin{array}{c}\text { Information technology based strategy } \\
\text { development }\end{array}$ & $\begin{array}{l}\text { Desarbo et al. (2005), Gonçalo (2013) and } \\
\text { Raymond and St-Pierre (2011). }\end{array}$ \\
\hline & SWOT analysis & $\begin{array}{l}\text { Andrews (1964), Daychouw (2007) and } \\
\text { Pearson et al. (2015). }\end{array}$ \\
\hline & Balanced scorecard & $\begin{array}{l}\text { Kaplan and Norton (1996; 2004; 2005; 2006), } \\
\text { Andersen, Cobbold and Lawrie (2001), } \\
\text { Bernardi, Silva and Batocchio (2012), Gomes } \\
(2006) \text { and Rocha (2002). }\end{array}$ \\
\hline
\end{tabular}




\begin{tabular}{|c|c|c|}
\hline & $\begin{array}{l}\text { Management systems } \\
\text { (ERP and CRM) }\end{array}$ & $\begin{array}{l}\text { Decourt (2013), Desarbo et al. (2005), Dyché } \\
\text { (2002), Newell (2000), Turban, Rainer and } \\
\text { Potter (2005). }\end{array}$ \\
\hline & Computer network & $\begin{array}{l}\text { Albano (2001), Bernardi et al. (2012), Desarbo } \\
\text { et al. (2005) and Vargas and Gonçalo (2013). }\end{array}$ \\
\hline \multirow{5}{*}{$\begin{array}{l}\text { Strategic } \\
\text { relations }\end{array}$} & Relationships with banks & $\begin{array}{l}\text { Carraresi et al. 2015, Freeman, Harisson, and } \\
\text { Wicks (2007), Sebrae (2010) }\end{array}$ \\
\hline & Relationships with customers & $\begin{array}{l}\text { Carraresi et al. (2015), Desarbo et al. (2005), } \\
\text { Rust, Zeithmal, and Lemon (2001) and Sebrae } \\
\text { (2010). }\end{array}$ \\
\hline & Relationships with sources & $\begin{array}{l}\text { Carraresi et al. (2015), Desarbo et al. (2005), } \\
\text { Freeman et al. (2007) and Sebrae (2010). }\end{array}$ \\
\hline & $\begin{array}{l}\text { Relationships with Unions, } \\
\text { Associations and Federations }\end{array}$ & $\begin{array}{l}\text { Carraresi et al. (2015), Centenaro and Laimer } \\
(2016) \text { and Freeman } \text { et al. (2007). }\end{array}$ \\
\hline & $\begin{array}{c}\text { Relationships with City and State } \\
\text { governments }\end{array}$ & $\begin{array}{l}\text { Carraresi et al. (2015), Freeman et al. (2007) } \\
\text { and Zeng, Xie and Tam (2010). }\end{array}$ \\
\hline \multirow{6}{*}{$\begin{array}{c}\text { Performance } \\
\text { focused strategy }\end{array}$} & Quality control program & Desarbo et al. (2005) and Sebrae (2010). \\
\hline & $\begin{array}{l}\text { Financial Management and Budget } \\
\text { Control }\end{array}$ & $\begin{array}{l}\text { Carvalho and Abramovay (2004), Cezarino and } \\
\text { Campomar (2006), Desarbo et al. (2005), } \\
\text { Gitman (2001) and Sebrae (2009). }\end{array}$ \\
\hline & Participation in Conventions and Fairs & $\begin{array}{l}\text { Angeloni (2002), Kotler and Kelvin (2006), } \\
\text { Sebrae (2010) and Terra (2000). }\end{array}$ \\
\hline & $\begin{array}{c}\text { Capacitation of Directors/Managers in } \\
\text { Business Strategy }\end{array}$ & $\begin{array}{l}\text { Angeloni (2002), Raymond and St-Pierre, 2011, } \\
\text { Silva and Ayres (2008) and Terra (2000). }\end{array}$ \\
\hline & $\begin{array}{l}\text { Consultancy in Business Strategy } \\
\text { related issues }\end{array}$ & $\begin{array}{l}\text { Paula and Wood (2008), Silva and Ayres (2008) } \\
\text { and Weber (2000). }\end{array}$ \\
\hline & Strategic Performance Assesment & $\begin{array}{l}\text { Kaplan and Norton (2005), Andersen et al. } \\
\text { (2001), Bernardi et al. (2012) and Rocha } \\
(2002) \text {. }\end{array}$ \\
\hline
\end{tabular}

Note -Table produced by the authors (2016).

To run a Structural Equations Model, we used the contents presented in Figure 2 and then we used theoretical concepts that converge with their similarities, as we will demonstrate latter.

The research data are primary, having been collected from an electronic survey methodology applied to the companies of the sample, which included managers from micro and small companies from the database of FEMICRO-CE (Federation of Small and Medium-Sized Enterprises of Ceará).
Using a five-point Likert scale, 400 questionnaires (Appendix A) were sent in 2014 and 196 valid responses were obtained, 114 microenterprises and 82 small companies.

The classification of the companies regarding the strategic capacity was made through the analysis of the Strategic Capacity Index, which we divided into five levels, based on the adjustment of the result, according to what is evidenced in Table 1.

Table 1 - Strategic Capacity Index Classification

\begin{tabular}{|c|l|}
\hline INDEX OF STRATEGIC CAPACITY & \\
& RANK \\
\hline $4<\mathrm{ICE} \leq 5$ & High Strategic Capability \\
\hline $3<\mathrm{ICE} \leq 4$ & Medium Strategic Capability \\
\hline $2<\mathrm{ICE} \leq 3$ & Low Strategic Capability \\
\hline $1<\mathrm{ICE} \leq 2$ & Very Low Strategic Capability \\
\hline $\mathrm{ICE}=1$ & Inexistent Strategic Capability \\
\hline
\end{tabular}

Nota. Table produced by the authors (2016). 
It should be emphasized that the definition of MSE can vary according to the methodology adopted by each country (Campos, Nishimura, Ramos, Cherez, \& Scalfi, 2008). Almeida and Moreira (2004) point out that the annual gross revenue and the number of employees are variables that must be analyzed for this classification. Another way of classifying is explained by Benczúr (2005), who also takes into account the number of hierarchical levels and the results in sales. This research was based on the General Law for MSE, Complementary Law 123 of 2006, which establishes that companies with a turnover of up to $\mathrm{R} \$ 360,000$ per year are micro-enterprises and companies with revenues greater than $R \$ 360,000$ and up to $R \$$ 3,600,000 are small (Brasil, 2006).

Multivariate analysis of the data was performed for the analysis. These data were evaluated by means of the Structural Equations Modeling (MEE) (Blunch, 2008; Fornell \& Larcker, 1981; Sharma, Durand \& Gur-Arie, 1981) by a second order confirmatory factorial analysis to search for consistency between the theoretical construct and the data obtained (Maroco, 2010).

The maximum likelihood (ML) method was used as a method to estimate the MEE measurements, since the Likert scale from five points with measures of asymmetry $(\mathrm{Sk}<3)$ and kurtosis $(\mathrm{Ku}<7)$ did not impact on Considerable distortions of normality that affect the estimates of this method (Finney \& Distefano, 2006).

To verify the degree to which the factors found satisfy the expected structure, a confirmatory factorial analys is (CFA) was performed. In order to do so, the indexes of quality of the $\chi^{2} / \mathrm{gl}$ adjustment (chi-square ratio and degrees of freedom), CFI (comparative fit index), TLI (Turomet-Lewis index), NFI (normed fit index) and RMSEA Mean square error of approximation) (Byrne, 2010; Maroco, 2010). The adjustment of the model was considered acceptable for values of $\chi^{2} / \mathrm{gl}$ lower than 5, IFI, TLI and NFI higher than 0.8 and RMSEA values up to 0.10 (Byrne, 2010; Maroco, 2010).

No outliers were identified by the Mahalanobis distance technique (Arbuckle, 2009), and the $\mathrm{Sk}<2$ and $\mathrm{Ku}<6$ values indicate the normality of the data.

The statistical software used was the Statistical Package for Social Sciences (SPSS) 20.0 and Analysis of Moment Structures (AMOS) 20.0 (Byrne, 2010; Hair, Anderson, Tatham \& Black, 2009; Maroco, 2010).

\section{RESULTS AND DISCUSSION}

The tests demonstrated that all the constructs are unidimensional presenting in the exploratory factorial, using the Kaiser method, commonalities higher than 0.50 , KMO above 0.7 for single factor. In addition, internal scale reliability tests were performed, which were measured using the Cronbach's alpha, the results can be observed in Table 2.

Table 2 - Cronbach's Alpha

\begin{tabular}{|l|c|}
\hline \multicolumn{1}{|c|}{ DIMENS IONS } & CRONBACH'S ALPHA \\
\hline Strategic processes & 0,905 \\
\hline Analysis of environments & 0,852 \\
\hline Strategic approach & 0,820 \\
\hline Strategic relations & 0,775 \\
\hline Strategic tools & 0,723 \\
\hline Performance-focused strategy & 0,264 \\
\hline
\end{tabular}

Nota. Table produced by the authors after the results of the study (2016).

Considering that, according to Hair et al. (2009), the minimum acceptability values are 0.6 to 0.7 , the "performance-focused strategy" dimension had to be disregarded.

In an in-depth analysis of the variables forming the dimension "Strategy focused on performance" (Total Quality Program, Financial Management and Budget Control, Participation in Congresses and Fairs, Training of the Board of Directors / Management in Business Strategy, Contracting of Consultancy in Issues related to Strategy and Strategic Performance
Evaluation), it can be seen that although they do characterize in fact items that will increase strategic capability, these variables are not usually used by MSE, since they are organizations managed by the owners, who do so informally and Based on empiricism (Boohene, 2009; Cezarino \& Campomar, 2006; Lerner \& Almor, 2002; Oliveira \& Sade, 2016; Vieira, 2007).

According to Byrne (2010), for the application of the second-order confirmatory factor analysis we 
suggest an initial verification of the model in a firstorder analysis.

The model of Figure 3 refers to the five valid dimensions related to strategic capability (strategic focus, strategic process, analysis of environments, strategic tools, and strategic relations) adjusted to a sample of 196 companies.

Figure 3 - First order confirmatory factorial analys is

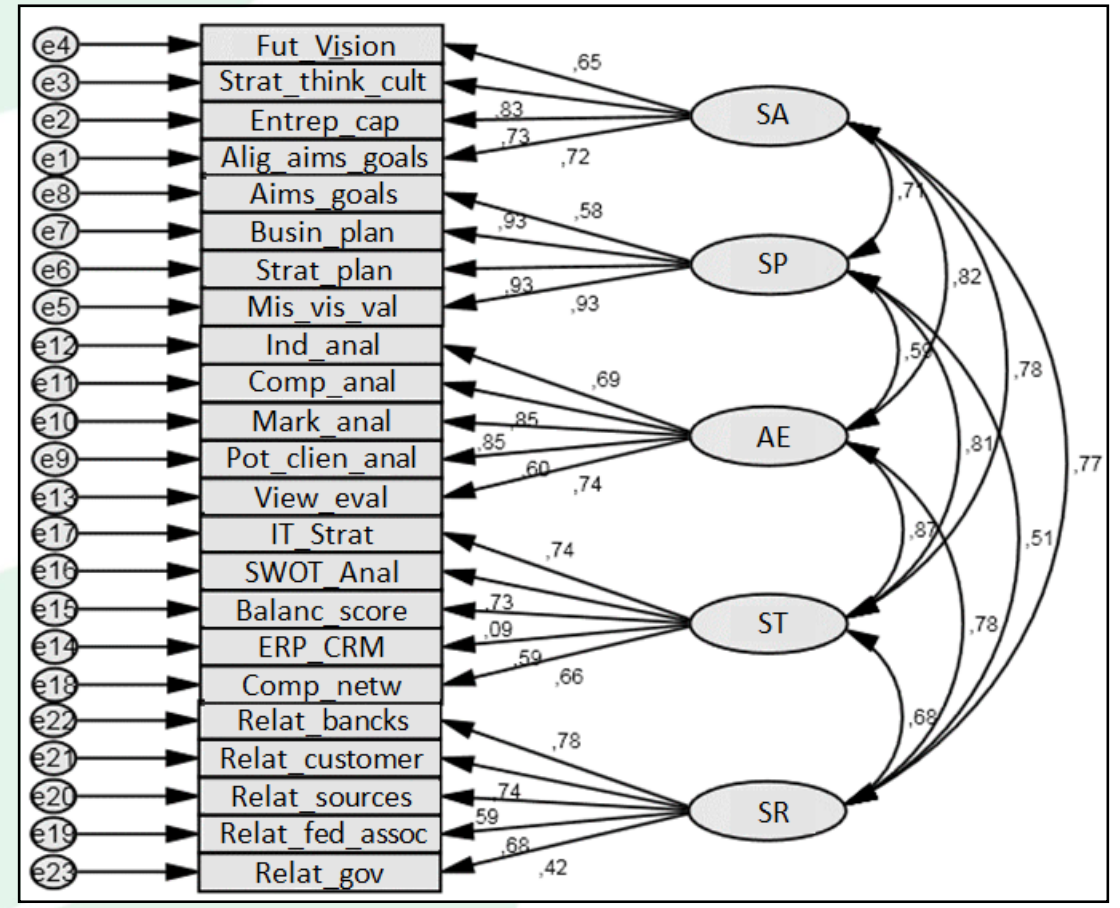

The model revealed unacceptable quality of adjustment $\left(\chi^{2} / \mathrm{gl}=3,778, \mathrm{CFI}=0.796\right.$, TLI $=0.765$, NFI $=0.744$, RMSEA $=0.119)$, considering the parameters listed by Byrne (2010), Maroco (2010) and Pearson et al. (2015).

In order to improve the model, following the guidelines of Byrne (2010), the variable, which was tied to the Strategic Tools dimension, was eliminated due to the low factor load (0.086), Balanced scorecard, which is considered an important tool that aligns the organization's strategies and ascertains its performance, providing managers with a comprehensive view of the entire company and providing the information needed to correct deficiencies and thus deliver superior results (Andersen, Cobbold \& Lawrie, 2001; Bernardi et al.,2012; Kaplan \& Norton, 1996; 2004; 2005; 2006).

It should be emphasized that, like the variables that made up the "performance-focused strategy" dimension, MSE do not usually make use of this instrument, since their management is usually done in an informal way, based on less complex instruments (Boohene, 2009, Cezarino \& Campomar, 2006, Lerner \& Almor, 2002, Oliveira \& Sade, 2016; Vieira, 2007).

In addition to the elimination of the afore mentioned variable, the strongly associated errors belonging to the same construct were correlated, as suggested by Byrne (2010) and Maroco (2010).

With the adaptations, the model became acceptable $\left(\chi^{2} / \mathrm{gl}=2.922, \mathrm{CFI}=0.877, \mathrm{TLI}=0.852\right.$, $\mathrm{NFI}=0.826$, RMSEA $=0.099)$, considering the parameters listed by Byrne (2010) and Maroco (2010).

Once the first order confirmatory factor analysis was considered adequate, a second order confirmatory factorial analysis was performed to meet the proposed objectives. Figure 4 shows the second-order model. 
Figure 4 - Second order confirmatory factorial analys is

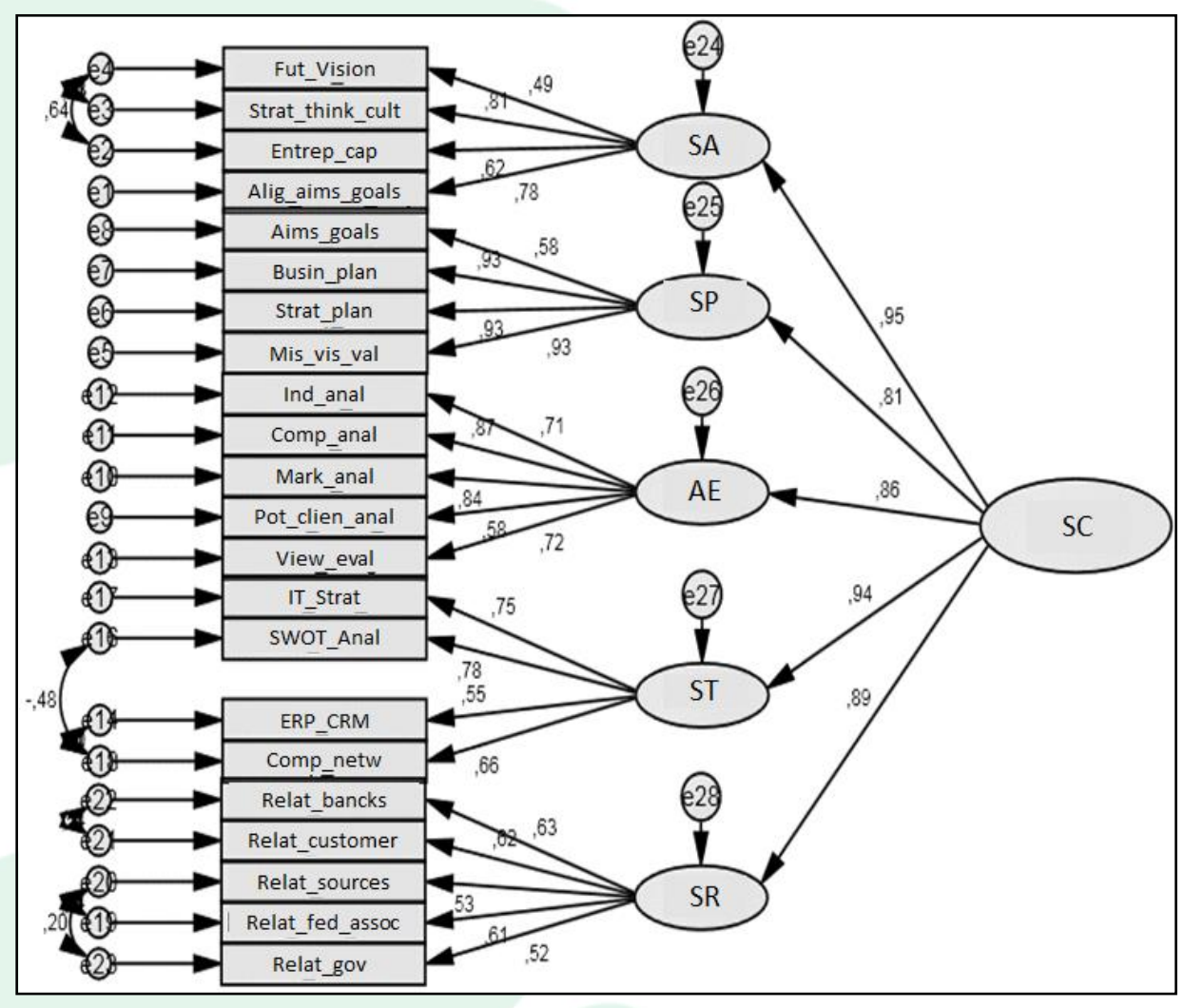

The second order model revealed acceptable quality adjustment $\left(\chi^{2} / \mathrm{gl}=2,944, \mathrm{CFI}=0.879\right.$, TLI $=$ $0.850, \mathrm{NFI}=0.830$, RMSEA $=0.100)$, considering the parameters listed by Byrne (2010) and Maroco (2010). According to the literature on strategic capability listed in Table 2, the constructs listed by the experts and categorized according to the literature are capable of indexing strategic capability.

The strategic capability obtained by the model of Figure 4 demonstrates that the decreasing order of influence of the constructs applied to this sample was: strategic approach (0.95); Strategic tools (0.94); Strategic relationships (0.89); Analysis of environments (0.86); and, finally, Strategic process $(0,81)$.

We observed that the more informal dimension which deals with the variables vision of the future, such as Thinking and strategic culture and Strategic alignment, presented the highest factor load (0.95), showing that, in agreement with Boohene (2009), Cezarino and Campomar (2006), Lerner and Almor (2002), Oliveira and Sade (2016) and Vieira (2007), MSE excel by the use of informal methods of management.

Regarding the second dimension with a higher factorial load (0.94), Strategic Tools, we found SWOT analysis as the most used tool, which is a tool used to engage in environmental analysis and itis used as the basis for the management and strategic planning of an organization. This is a simple and a low cost method that MSE uses to plan their strategies (Andrews, 1964;
Daychouw, 2007; Grandee 2014; Pearson et al., 2015). The use of this tool in this way, we observed that, as previously analyzed, the characteristics of the MSE are explicitly reflected in the constructed index.

As to the Strategic Relations dimension, which presented a factorial load of 0.89 , it should be pointed out that MSE, due to their scarcity of resources (Cesarino \& Campomar, 2006; GEM, 2012; Sebrae, 2014), seek partners and financiers to enable themselves (Johannesson \& Palona, 2010; Nonaka \& Takeuchi, 2005; Silva \& Ayres, 2008), which is based on the theory that knowledge is multiplied when it is shared, unlike what happens with land, capital and labor (Nonaka \& Takeuchi, 2005; Freeman et al., 2007). This finding is also in alignment with Carraresi et al. (2015), Raymond and St-Pierre, 2011 and Vargas and Gonçalo, 2013 which found that networking and marketing capabilities were key for firm performance.

The Analysis of Environments dimension, with a factorial load of 0.86 , represents strategic ways of diagnosing the context in which the organization is inserted. When analyzing the loads of the variables that compose this dimension, we observed that the one with the least impact is the analysis of potential customers, which corroborates with Gutiérrez et al. (2014) when this one considers that the companies that carry out this analysis do it for two reasons: (1) they wish to increase their sales volume; and or (2) replace customers who are being lost over time. Considering the profile of the companies analyzed, these are not the priorities for companies that seek to survive. 
Finally, regarding to the strategic process, we observed high factorial loads for formalized Business Plan, Strategic Planning and Formalized Mission, Vision, Values and Policies. The origin of the research population might be one explanation for this result, they were from FEMICRO-CE database companies, which in turn are related to Sebrae. This organization provide services for MSE in many areas of management, including strategic planning and guidance for entrepreneurs of all sorts of government compliance issues (Pearson et al., 2015; Grandee, 2014; Pisano, 2016; Sebrae, 2016).

The model presented allows identifying the strategic capability index by means of the formula:

SCI $=0,95 \times(0,49 \times$ Fut_Vision $+0,81 \times$ Strat_think_cult $+0,62 \mathrm{x}$ Entrep_cap $+0,78 \mathrm{x}$ Alig_aims_goals $)+0,94 \times(0,75 \times$ IT_Strat $+0,78 \times$ SWOT_Anal $+0,55 \mathrm{x}$ ERP_CRM $+0,66 \mathrm{x}$ Comp_netw $)+0,89 \times(0,63 \times$ Relat_bancks $+0,62 \times$ Relat_customers $+0,53 \mathrm{x}$ Relat_sources $+0,61 \mathrm{x}$ Relat_fed_assoc $+0,52 \times$ Relat_gov $)+0,86 \times(0,71 \times$ Ind_anal $+0,87 \times$ Comp_anal $+0,84$ x Mark_anal + $0,58$ x Pot_clien_anal $+0,72 \mathrm{x}$ View_eval $)+0,81 \mathrm{x}$ $(0,58 \times$ Aims_goals $+0,93 \times$ Busin_plan $+0,93 \times$ Strat_plan $+0,93 \times$ Mis_vis_val)

Applying the proposed formula to the companies from the study sample, the average strategic capability index of the entire group analyzed was low, according to the classification indicated in Figure 1, reaching the value of 2.71. This result corroborates with other national studies (Dumbu \& Chadamoyo, 2012; Herrera, 2007; SBA, 2013; Tlhomola, 2010), that has already pointed out that MSE's suffer structural problems in their management which end up directly impacting their strategic capability.

Segregating the sample in micro and small companies, it was verified that the indices of strategic capability are, respectively, 2.56 and 2.99. This shows that both micro and small firms have a low strategic capability index, however, this index approaches the median when it comes to small companies, which reinforces the findings of other research (Aaker, 2001; Moen, 1999; Perin \& Sampaio, 2004), which, in short, consider that larger companies have more resources and are more apt to become competitive.

\section{CONCLUSION}

The main objective of the study was to elaborate a strategic capability index of MSE, through the conceptual alignment of MSE characteristics and strategic capabilities.

Through a second order confirmatory factorial analysis applied to 196 companies listed in the database of FEMICRO Cearense, the analysis of the collected information allowed to construct a scenario about the strategic capacities of the MSE.
The research proposed a formula for measuring a strategic capability index of MSE, factoring the constructs: strategic approach (0.95); Strategic tools (0.94); Strategic relationships (0.89); Analysis of environments (0.86); and strategic processes $(0,81)$.

The application of the index revealed an average strategic capability of 2.71 for all the companies in the sample, corroborating previous research (Cezarino \& Campomar, 2006; Dumbu \& Chadamoyo, 2012; Herrera, 2007; Sebrae, 2010; Terence, 2002; Thomola, 2010).

In a segregated analysis, we noticed that the index of strategic capability of small companies was higher in relation to said index of the microenterprises, which is in agreement with the results of previous research (Aaker, 2001; Moen 1999; Perin \& Sampaio, 2004).

The proposal of the strategic capability index contributes to the reduction of a gap in the literature and operationalizes its measurement, which allows the identification of aspects to be developed with the purpose of achieving and increasing its own strategic management capabilities (Bohene, 2009; Lerner \& Almor, 2002).

One of the limitations of this research is the origin of the research population, they were from FEMICRO-CE database companies, which in turn are related to Sebrae, which has consolidated strategic characteristics, which can standardize the standard of action of the companies advised.

\section{REFERENCES}

Aaker, D. A. (2001). Administração estratégica de mercado. Porto Alegre: Bookman.

Albano, C. S. (2011). Problemas e ações na adoção de novas tecnologias de informação: um estudo em cooperativas agropecuárias do Rio Grande do Sul. Dissertação de Mestrado. Universidade Federal do Rio Grande do Sul. Porto Alegre, RS, Brasil.

Almeida, A. C. (2001). Como utilizar dados agregados para formular índices: $O$ caso do índice de qualidade dos municípios - Carências. Anais do Seminário Fluminense de Indicadores. Rio de Janeiro, RJ, Brasil.

Almeida, M. I. R. \& Moreira, A. L., Jr. (2004). A Análise do Ambiente Organizacional na Pequena Empresa: Um Estudo em PME'S na cidade de São Paulo. Anais do Congresso Latino-Americano de Estratégia. Santa Cruz de la Sierra, Bolívia.

Alves, V. M. (2003). Adoção do conceito de estratégia na gestão das pequenas e médias empresas do ramo de drogaria localizadas na região da Grande Goiânia. Dissertação de Mestrado. Universidade 
Federal de Santa Catarina. Florianópolis, SC, Brasil.

Andersen, H., Cobbold, I. \& Lawrie G. (2001). Balanced Scorecard implementation in SME's: reflection on literature and practice. SME-SME INTERNATIONAL. CONFERENCE. Allborg. Allborg University: Denmark.

Andrews, K. (1964). Estratégia empresarial. São Paulo: Makron Books.

Angeloni, M. T. (2002). Organizações do conhecimento: infraestrutura, pessoas e tecnologias. São Paulo: Saraiva.

Ansoff, H. I. (1984). Implanting strategic management. Englewood Cliffs: Prentice-Hall International.

Bannister, B. D. \& Higgins, R. B. (1991). Strategic Capability, Corporate Communications and Strategic Credibility. Academy of Management Proceedings. 1, 2-6.

Barney, J.B. \& Hesterly, W. S. (2011). Administração estratégica e vantagem competitiva: conceitos e casos. 3. ed. São Paulo: Pearson Prentice Hall.

(1990). The debate between traditional management theory and organizational economics: substantive differences or intergroup conflict? Academy of Management Review, 15: 382-393.

(1991). Firm resources and sustained competitive advantage. Journal of Management. 17(1), 99-120.

Benczúr, D. (2005). Environmental scanning: how developed is information acquisition in Western European companies? IR Information Research. 11(1), 0-0.

Bernardi, T., Silva, D. I. \& Batocchio, A. (2012). Roteiro para implantação de Balanced Scorecard: estudo de caso em pequena empresa. Revista de Ciência \& Tecnologia. São Paulo, 17(33), 87-102.

Blunch, N. (2008). Introduction to structural equation modelling using SPSS and AMOS. London: Sage.

Boohene, R. (2009). The Relationships Among Gender, Strategic Capabilities, and Performance of Small Retail Firms in Ghana. Journal of African Business. 10(1), 121-138.

Brasil. (2006). Lei Complementar n 123, de 14 de dezembro de 2006. Institui o Estatuto Nacional da Microempresa e da Empresa de Pequeno Porte. Diário Oficial [da] República Federativa do Brasil, Brasília, DF, 14 dez. 2006.
Byrne, B. M. (2010). Structural Equation Modeling with AMOS: Basic Concepts, Applications, and Programming. New York, NY: Routledge.

Campos, J. G. F. de, Nishimura A. T., Ramos H. R., Cherez R. L. \& Scalfi V. B. (2008). As pequenas e médias empresas no Brasil e na China: uma análise comparativa. São Paulo: Universidade de São Paulo.

Canzano D. \& Grimaldi M. (2012). An integrated framework to implement a knowledge management programme: the role of technological tools and techniques. International journal of intelligent enterprise - IJIE. 1(3-4), 233-247.

Carraresi, L., Mamaqi, X., Albisu, L. M. \& Banterle, A. (2015). Can Strategic Capabilities Affect Performance? Application of RBV to Small Food Businesses. Agribusiness, 1-21.

Carvalho, C. E. \& Abramovay, R. (2004). O Difícil $e$ Custoso Acesso ao Sistema Financeiro. Brasília: Sebrae.

Centenaro, A. \& Laimer, C. (2016). Cooperative relationships and competitiveness in supermarket sector. Review of Business Management, 0 . doi:http://dx.doi.org/10.7819/rbgn.v0i0.3070

Cezarino, L. O. \& Campomar, M. C. (2006). Micro e Pequenas Empresas: características estruturais e gerenciais. Revista HISPECI \& LEMA. 9(1), 10-12.

Collins, J. \& Porras, J. (2002). Built to last. New York: Harper Business.

Collis, D. \& Montgomery, C. A. (1995). Competing on resources. Havard Business Review, July/Aug.

Davood, G.\& Mousakhani M. (2012). Knowledge management capabilities and SME's organizational performance. Journal of Chinese Entrepreneurship. 4 (1), 35-49.

Daychouw, M. (2007). 40 Ferramentas e Técnicas de Gerenciamento. 3. ed. Rio de Janeiro: Brasport.

Decourt, F. R. (2013). Integrar o CRM e o ERP, o novo desafio da tecnologia da informação. São Paulo: FAEG, Associação Cultural e Educacional de Garça - ACEG, Garça.

Desarbo, W. S., Di Benedetto, C. A., Song, M. \& Sinha, I. (2005). Revisiting the Miles and Snow Strategic Framework: Uncovering Interrelationships between Strategic Types, Capabilities, Environmental Uncertainty, and firm 
Performance. Strategic Management Journal, 26 (1), 47-74.

Desouza, K. C. \& Awazu, Y. (2006). Knowledge management at SMEs: Five peculiarities. Journal of Knowledge Management. 10(1), 32-43.

Dias, B. B. B. T. A., Cassol, A., Tonial, G. \& Rossetto, R. C. (2013). Estudo da Adaptação Estratégica e das Capacidades Estratégicas da empresa Celulose Irani S.A. Anais do Encontro Anual da Associação Nacional dos Programas de Pós-Graduação em Administração. Rio de Janeiro, RJ, Brasil, 37.

Dierickx, I. \& Cool, K. (1989). Asset stock accumulation and sustainability of competitive advantage. Management Science, 35(12).

Dornelas, J. C. A. (2008). Empreendedorismo corporativo: como ser empreendedor, inovar e se diferenciar em organizações estabelecidas. Rio de Janeiro: Elsevier.

Dumbu, E. \& Chadamoy, P. (2012). Managerial deficiencies in the Small and Medium Enterprises (SMEs) in the craft industry: An empirical evidence of SMEs at Great Zimbabwe in Chief Mugabe's area. European Journal of Business and Management. 4(10), 79-85.

Durst, S.\& Wilhelm, S. (2013). Do you know your knowledge at risk? Measuring Business Excellence. 17(3), 28-39.

Dyché, J. (2002). The CRM Handbook: A Business Guide to Customer Relationship Management. Indiana-USA: Addison-Wesley.

Edvardsson, I. R. \& Durst, S. (2013). The benefits of knowledge management in small and medium-sized enterprises. Procedia - Social and Behavioral Sciences. 81, 351-354.

Finney, S. J. \& Distefano, C. (2006). Non-normal and categorical data in structural equation modeling. In: Hancock, G R.; Mueller, R. O. (Eds.). Structural Equation Modeling: A second course. Greenwich, CT: Information Age Publishing, 269-314.

Fornell, C. \& Larcker, D. F. (1981). Evaluating Structural Equation Models with Unobservable Variables and Measurement Error. Journal of Marketing Research. 18(1), 39-50.

Freeman, R. E., Harrison, J. S. \& Wicks A. C. (2007). Managing for Stakeholders: Survival, Reputation and Success. New Haven: Yale University Press.
Gerber, M. (1995). The E-Myth Revisited: Why Most Small Businesses Don't Work and What to Do About It. Harper Collins.

Gimenez, F. A. P. (2000). O estrategista na pequena empresa. Maringá: Edição do autor, 1.

Gitman, L. J. (2001). Princípios de administração financeira - essencial. 2. ed. Porto Alegre: Bookman.

Global Entrepreneurship Monitor - GEM. (2012). $O$ sonho de ter o próprio negócio é maior que ter uma carreira em empresa. São Paulo. Disponível em: $<$ http://www.Sebrae.com.br/customizado/estudos -epesquisas/temasestrategicos/empreendedorismo>. Acesso em: 18 mar. 2013.

Gomes, L. V. de C. (2006). Adaptação do BSC para as MPE's brasileiras: uma pesquisa-ação. Dis sertação de Mestrado. Faculdades Ibmec. Rio de Janeiro, RJ, Brasil.

Grandee, T. A. (2014). Strategic planning in small business: Exploring its influence on transitional growth. Capella University. DBA (Thesis), School of Business and Technology, Minnesota: USA.

Gutiérrez, P. R., Fuentes, M. del M. \& Ariza, L. R. (2014). Strategic capabilities and performance in women-owned businesses in Mexico. Journal of Small Business Management, 52(3), 541-554.

Hair, J. F., Jr., Anderson, R. E., Tatham, R. L. \& Black, W. C. (2009). Análise multivariada de dados. Porto Alegre: Bookman.

Harrison, R. \& Miller, S. (1999). The Contribution of Clinical Directors to the Strategic Capability of the Organization. British Journal of Management. 10, 23-39.

Hartman, D. (2013). O que é Capacidade Estratégica? Disponível em: $<$ http://smallbusiness.chron.com/strategiccapability-15828.html>. Acesso em: 16 mai. 2015.

Helfat, C. \& Peteraf, M. (2003). The dynamic resourcebased view: capability lifecycles. Strategic Management Journal. 24 (10), 997-1010.

Herrera, B. (2007). Knowledge Management as an Effective Tool to Improve Economic Performance in Micro and Small Enterprise. Tese de Doctorado. ESADE/ESAN. Lima, Peru.

Hoskisson, R. E., Hitt, M. A., Ireland, R. D. \& Harrison, J. S. (2009). Estratégia competitiva. São Paulo: Cengage Learning. 
Johannesson, J. \& Palona, I. (2010). The Dynamics of Strategic Capability. International Business Research.3(1), 3-12.

Jung, C. F. (2004). Metodologia para pesquisa \& desenvolvimento: aplicada a novas tecnologias, produtos e processos. Rio de Janeiro: Axcel Books.

Kaplan, R. S. \& Norton, D. P. (1996). The balanced scorecard: translating strategy into action. Harvard Business Press.

(2004). Strategy maps: converting intangible assets into tangible outcomes. Boston, MA: Harvard Business School Publishing Corporation.

(2005). The balanced scorecard: measures that drive performance. Harvard Business School Publishing.

(2006). Alignment: Using the balanced scorecard to create corporate synergies. Harvard Business Press.

Kotler, P. \& Kelvin, K. L. (2006). Administração de Marketing. 12. ed. São Paulo: Pearson Prentia Hall.

Lerner, M. \& Almor, T. (2002). Relationships among Strategic Capabilities and the Performance of Women-Owned Small Ventures. Journal of Small Business Management. 40(2), 109-125.

Lima, S. M. \& Vasconcelos, A. C. de. (2016). Ciclo de vida organizacional e ativos intangíveis de Empresas de Base Tecnológica Incubadas. Revista de Administração de Roraima-RARR. 6(1), 128155 .

Low, J. \& Kalafut, P. C. (2003). Vantagem invisível: como os intangíveis conduzem o desempenho da empresa. Porto Alegre: Bookman.

Maia, H.L. (2017). De empresa familiar para família empresária. Editora Dummar: Fortaleza.

Malhotra, N. K. (2006). Pesquisa de Marketing: Uma orientação aplicada. 4. ed. Porto Alegre: Bookman.

Maroco, J. (2010). Análise estatística: Com utilização do SPSS. Lisboa: Edições Sílabo.

Mathaisel, D.F.X \& Comm, C.L.A. (2011). Strategy for Enterprise Sustainability. The Business Review.17(1), 0.

McGahan, A. M. (2004). "How industries change." Harvard business review 82.10.
Mintzberg, H., Ahlstrand, B. \& Lampel, J. (2000). Safári de estratégia: um roteiro pela selva do planejamento estratégico. Porto Alegre: Bookman.

Moen, O. (1999). The relationship between firm size, competitive advantages and export performance revisited. International Small Business Journal. 18 (1), 53-72.

Morais, I. D. C. de \& Soares, A. M. (2016). Impacto do Marketing Interno sobre a Orientação para o Mercado em Empresas Brasileiras. Revista de Administração Contemporânea, 20(2), 197-215.

Nassif, V. M. J., Hashimoto, M., \& Amaral, D. J. (2014). Entrepreneurs self-perception of planning skills: evidences from Brazilian entrepreneurs. Revista Ibero-Americana de Estratégia, 13(4), 107121.

Newell, F. (2000). Fidelidade.com. São Paulo: Makron Books.

Nonaka, I. \&Takeuchi, H. (2008). Gestão do Conhecimento. Porto Alegre: Bookman.

Nunes, M.B., Annansingh, F., Eaglestone, B. \& Wakefield, R. (2006). Knowledge management issues in knowledge-intensive SMEs. Journal of Documentation.62 (1), 101-119.

Oliveira, P. H. \& Sade, W. (2016). Inteligência competitiva no contexto das empresas mineiras de artefatos de estanho. Perspectivas em Ciência da Informação. 21 (1), 23-41.

Paim, N. A., Lara, J. E. \& Christino, J. M. M. (2011). Relações quantitativas entre orientação para o mercado, desempenho organizacional e a percepção externa de sucesso em instituições de pesquisas tecnológicas afiliadas à ABIPTI. Revista de Administração Contemporânea, 15(6), 1059-1077.

Paula, A. P. P. de \& Wood, T., Jr. (2008). Dilemas e ambiguidades da 'indústria do conselho': um estudo múltiplo de casos sobre empresas de consultoria no Brasil. RAC-Eletrônica. 2(2), 171-188.

Pearson, J., O'Connell, J. F., Pitfiel, D. \& Ryley, T. (2015). The strategic capability of Asian network airlines to compete with low-cost carriers. Journal of Air Transport Management, 47, 1-10.

Penrose, E. T. (1959). The theory of the growth of the firm. New York: John Wiley.

Perin, M. G. \& Sampaio, C. H. (2004). Orientação para o Mercado, Porte Empresarial e Performance: um estudo longitudinal no setor Eletroeletrônico do 
Brasil. RAE - Revista de Administração de Empresas. 44(3), 76-88.

Pinto, L. (2001). Sistema nacional de índices de preços ao consumidor. Anais do Seminário Fluminense de Indicadores. Rio de Janeiro, RJ, Brasil.

Pisano, G. P. (2016). Towards a Prescriptive Theory of Dynamic Capabilities: Connecting Strategic Choice, Learning, and Competition. Harvard Business School Technology and Operations Management Unit Working Paper. 16(146).

Porter, M. E. (1985). Vantagem competitiva. São Paulo: Elsevier.

Porter, M. E. (1986). Estratégia Competitiva: Técnicas para Análise de Indústria e da Concorrência. 7. ed. Rio de Janeiro: Elsevier.

Programa das Nações Unidas para o Desenvolvimento. (2007). Relatório de Desenvolvimento Humano 2000. Lisboa: Trinova.

Raymond, L. \& St-Pierre, J. (2011). Strategic capability configurations for the internationalization of SMEs: A study in equifinality. International Small Business Journal, 31(1), 82-102.

Ribeiro, A. B, Neto. (2008). Fatores que impactam o desempenho de pequenas empresas. Tese de Doutorado. Universidade Federal do Rio de Janeiro, Rio de Janeiro, RJ, Brasil.

Rocha, A. C. B. (2002). Configuração de um sistema de avaliação de desempenho alicerçado no balanced scorecard para uma indústria de confecções de porte médio. Dissertação de Mestrado. Universidade Federal de Santa Catarina. Florianópolis, SC, Brasil.

Rust, R. T., Zeithaml, V. A. \& Lemon, K. N. (2001). Driving customer equity: How customer lifetime value is reshaping corporate strategy. Simon and Schuster.

Serviço Brasileiro de Apoio às Micro e Pequenas Empresas. (2010). 12 Anos de Monitoramento da Sobrevivência e Mortalidade de Empresas. São Paulo.

Anuário do Trabalho na Micro e Pequena Empresa: 2009. (2010). São Paulo.

Como começar bem. (2016). Brasília.

Departamento Intersindical de Estatística e Estudos Socioeconômicos. (2013). Anuário do trabalho na micro e pequena empresa - 2013. Brasília.

(2015). Participação das Micro e Pequenas Empresas na Economia Brasileira. Brasília.

(2014). Participação das Micro e Pequenas Empresas na Economia Brasileira. Brasília.

Sharma, S., Durand, R. M. \& Gur-Arie, O. (1981). Identification and analysis of moderator variables. Journal of marketing research. 18 (3), 291-300.

Silva, S. R. da \& Ayres, S. M. R. de. (2008). A identificação das fontes de formação das capacidades estratégicas da operação. Revista Gestão.Org. 6(1), 73-89.

Small Business Administration - SBA. (2013). The US Small Business Administration. Disponível em: <http://www.sba.gov/>. Acesso em: 18 mar. 2013.

Terence, A. C. F. (2002). Planejamento Estratégico como Ferramenta Competitividade na Pequena Empresa: Desenvolvimento e Avaliação de um Roteiro Prático para o Processo de Elaboração do Planejamento. Dissertação de Mestrado. Universidade de São Paulo. São Carlos, SP, Brasil.

Terra, J. C. C. (2000). Gestão do conhecimento o grande desafio empresarial: uma abordagem baseada no aprendizado e na criatividade. São Paulo: Negócio.

Thlomola, J. S. (2010). Failure Of Small Medium \& Micro Enterprises In The Tshwane Metropolitan Municipality. Submitted In: Partial Fulfilment of the Requirements For The Degree Magister Technologie: Entrepreneurship. In: The Department of Management And Entrepreneurship Faculty Of Management Science Tshwane University of Technology.

Trindade, E. P., Macedo, M., Gauthier, F. A. O., Botelho, L. de L. R. \& Lanblak, S., Jr.(2016). Soluções de gestão do conhecimento para pequenas e médias empresas - PME. Perspectivas em Gestão \& Conhecimento.6 (Número Especial), 189-203.

Turban, E., Rainer, K. R. \& Potter, E. R. (2005). Administração de tecnologia da informação: teoria e prática. Rio de Janeiro: Elsevier.

Vargas L. M. S. \& Gonçalo R. C. (2013). Capacidades estratégicas voltadas para inovação: um estudo na empresa Softplan. Anais do Encontro Nacional de Engenharia de Produção. Salvador, BA, Brasil. 
Vieira, L. M. (2007). A Contribuição das Micro $e$ Pequenas Empresas para a Redução da Pobreza no Brasil. Dissertação de Mestrado. Universidade Federal do Ceará. Fortaleza, Ceará, Brasil.

Weber, M. (2000). Economia e Sociedade: Fundamentos da Sociologia Compreensiva. Brasília: Universidade de Brasília.

Wernerfelt, B. A. (1984). Resource-Based View of the Firm. Strategic Management Journal, 5(2), 171180.
Wong, K. Y. \& Aspinwall, E. (2005). An empirical study of the important factors for knowledge-management adoption in the SME sector. Journal of Knowledge Management. 9(3), 64-82.

Zeng, S. X., Xie, X. M. \& Tam, C. M. (2010). Relationship between cooperation networks and innovation performance of SMEs. Technovation. 30(3), 181-194. 


\section{APPENDIX A}

\section{Research questionnaire}

Dear participants,

We are researchers of the Postgraduate Program in Administration of UNIFOR - University of Fortaleza.

The Strategy is the part of the Administration that deals with important, prominent, far-reaching, great-effect decisions of a company; those that empower and direct companies to compete with the competitive market.

With the focus on small and medium-sized companies, the objective of this research is to propose an indicator of the strategic capacity of micro and small enterprises (MSB). The relevance of this study is justified by the fact that there is a need for academic studies that seek to understand the particularities that involve the strategic capacity of micro and small companies, since there is a gap in the literature regarding small and medium businesses in this area.

This research will be useful as a tool to help managers and other stakeholders about the scientific knowledge in the field of small business administration, as well as the use of the MSB strategic capacity assessment tool, which will be made available, thus enabling the development reflections and actions that should directly influence the performance of organizations.

We ask for your assistance in completing the following questionnaire. Note that there is no need to identify the respondent, nor the company, and thus, their identities will be preserved. Their participation is fundamental to the success of this research.

To answer the questionnaire you must express your opinion on the level of adoption of the variables that make up the strategic business capacity adopted by your company. The scale varies from:

1 - Do not Adopt

2 - Adopt Weakly

3 - Moderate Adoption

4 - Adopt satisfactorily

5 - Strongly Adopt

We also ask you to indicate other variables that you think fit, indicating the level of Strategic Capacity Practice of your company.

As the theme is business strategy, this research should be answered by any of the following company: owner, entrepreneur, partner, director or general manager. You will respond to the questionnaire within 20 minutes. We are convinced that this work will help your company evaluate and develop more competitive capacity.

1. How big is your company?

Micro enterprise

Small business

Average company

Big company

2. How long has your company been in the market?

Up to 2 years

Up to 05 years

Up to 10 years

More than 15 Years

3. Which sector is the main economic activity of your company?

Industry

Trade

Service

4. What is the level of adoption of the variables that make up the strategic business capacity adopted by your company?

1. Vision of the Future in the Organization

2. Thinking and Strategic Culture

3. Entrepreneurial Capability

4. Focus on the Alignment of Goals and Objectives to the Company's Mission

5. Formally Defined Goals and Objectives 
6. Formalized Business Plan

7. Systematized Strategic Planning

8. Mission, Vision, Values and Policies Formalized.

9. Analysis of Industry (suppliers, rivals, buyers, substitute products)

10. Analys is of Competition

11. Market Analys is

12. Analysis of Potential Clients

13. Evaluation of the Company's Image in the Market

14. Formation of the Strategy Based on Information Technology

15. SWOT / FOFA analysis

16. Balanced Scorecard

17. Management Systems (ERP) and (CRM)

18. Networked Computers

19. Focus on Cost Strategy

20. Downsizing of Organizational Structure and Administrative Expenses

21. Debt Renegotiation Strategy

22. Competition Differentiation Strategy

23. Market Focus Strategy (niche, segment and personalized service)

24. Point of Sale Strategy

25. Strategy of Modernization or Expansion of the Business

26. Market Growth Strategy in Brazil

27. Indirect Export (through intermediaries)

28. Direct Export (the company performs abroad)

29. Product Innovation Program

30. Process Innovation Program

31. Development / Diversification of Products and Services

32. Diversification - Creating a brand new business

33. Business Acquisition Strategy

34. Total Quality Program

35. Financial Management and Budgetary Control

36. Participation in Congresses and Fairs

37. Relationship with Banks

38. Relationship with Clients

39. Relationship with Suppliers

40. Relationship with Unions, Associations and Federations

41. Relationship with Municipal and State Government

42. Training of the Board of Directors / Management in Business Strategy

43. Recruitment of Consultancy in matters related to Business Strategy

44. Strategic Performance Assessment

5. If you want to suggest any variables, please include below, at the respective level of adoption (scale) of your company. 